\title{
Cast metal matrix composites-challenges in processing and design
}

\author{
SUBRATA RAY \\ Department of Metallurgical Engineering, University of Roorkee, Roorkee 247667 , India
}

\begin{abstract}
Development of metal matrix composites has extended the choice of materials particularly for the space, aero-space and automobile industries, with a view to reduce fuel consumption and operating cost by weight saving. Tailoring of a composite to suit a given application requires choice of constituents and promotion of desirable interfaces. Solidification processing of composites demands particular attention to wetting of dispersoids by alloys, defects like porosities and evolution of microstructures particularly in respect of changing the nature of interfaces in a composite.
\end{abstract}

Keywords. Metal matrix composite; solidification processing; interface.

\section{Introduction}

Metal matrix composites (MMC) have taken the search for new materials beyond the realm of monolithic metals and alloys which are limited by the phase equilibria - the dictates of nature. The constituents of a composite can be freely selected by a materials engineer to impart in it, a spectrum of property required for a given application.

The space and aerospace industries were quick enough to realize the potential of this emerging class of materials as it might lead to weight saving which has a high premium for them. It costs on an average Rs 1.5 to 4.5 lacs to launch each kilogram into orbit and therefore, a satellite designer is always on the lookout for lighter materials capable of withstanding vibrations and g-force of a launch (Charles 1990). Reusable spacecrafts like space shuttle was the first major project to use MMC. Its cargo bay structure was supported by 243 boron-aluminium tubes. Discontinuously reinforced aluminium with $40 \mathrm{vol} \%$ whisker or particulate, had been used in guidance component of Trident missiles. Graphite reinforced aluminium has been used in tubular struts of space structures due to its lightweight and almost zero coefficient of thermal expansion (CTE).

The objective of weight saving is also relevant in an aircraft because every extra kilogram of structural mass reduces the vehicle's payload capability by the same amount and enhances the fuel consumption and operating cost. Structural weight reduction through improved properties and the consequent reduction in fuel consumption are shown in figures $1 \mathrm{a}$ and $1 \mathrm{~b}$ (Hartmann and Kellerer 1986). SiC fibre reinforced titanium which is about three times stronger for a given weight than nickel base superalloys, has been used in compressor discs of aero-engines. SiC fibre reinforced titanium aluminide has a specific strength twice that of Inconel 718 and is a strong candidate for use in compressor blades, vanes and rotors. The report on project ATF (advanced tactical fighter), USA, concludes that MMCs can compete with titanium and thermoplastics assuming a weight saving value of $\$ 200$ per pound (Charles 1990). But the attention of space and aerospace industries could not generate widespread industrial interest in MMCs because the space and aerospace sector is a low volume materials consumer.

The reduction in operating cost due to weight saving in ground transportation is considerably less compared to that in space or aerospace industries. However, the oil 




(a)

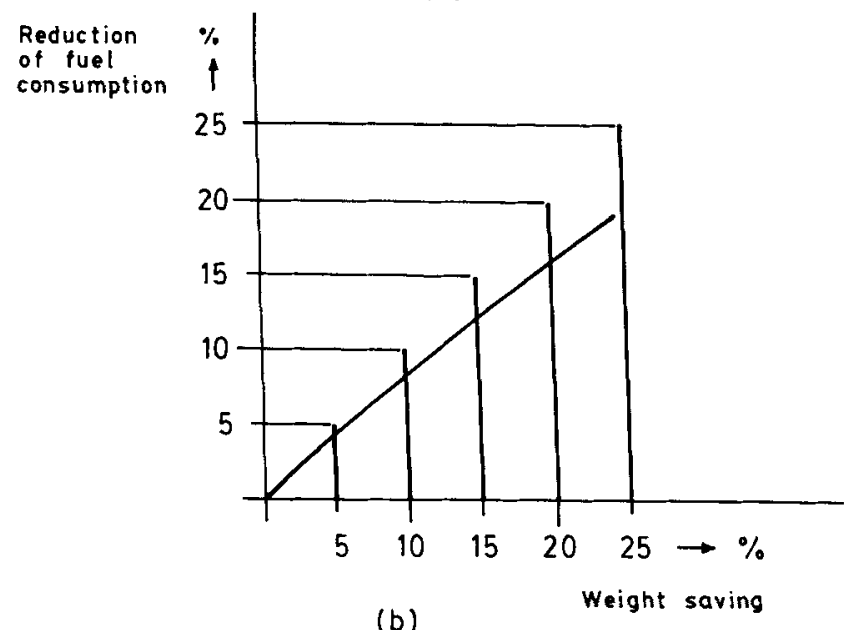

Figure 1. Effect of material property improvement on weight saving and reduction in fuel consumption.

crisis in mid seventies compelled the car manufacturers to look for lighter materials and aluminium alloys entered the automobile sector. Since weight saving in a vehicle will reduce the requirement of engine capacity for the same engine performance, the price of a car will become cheaper. The cutting edge of competition is therefore keeping the agenda of weight saving alive in automobile sector. Also, weight saving is extremely important in the context of development of electric vehicles. But a relatively lower. premium on weight saving compels the automobile industries to look for cheaper materials and it has already generated a significant amount of industrial production of cast MMCs as evident from a selected list of manufacturers given in table 1.

Research on cast composite in India started as early as 1969 when the author, a postgraduate student at IIT, Kanpur, developed stircasting technique and synthesized $\mathrm{Al}-\mathrm{Al}_{2} \mathrm{O}_{3}$ particle reinforced composites for the first time (Ray 1969). Magnesium was identified as the addition agent to promote wettability of alumina particles by molten aluminium. In early seventies considerable research activity on cast composites generated at IISc, Bangalore, RRL, Trivandrum and elsewhere (Ray 1993), but interest in cast MMCs in India remained mostly academic, possibly due to an absence of organic link between the industries and the institutes. 
Table 1. Selected list of manufacturers of MMC ingots.

\begin{tabular}{llcr}
\hline Manufacturers & Composites & $\begin{array}{c}\text { Production } \\
\text { technique }\end{array}$ & $\begin{array}{c}\text { Capacity } \\
\text { tons/yr }\end{array}$ \\
\hline $\begin{array}{l}\text { DURALCAN, USA } \\
\text { BP Metal }\end{array}$ & $\begin{array}{l}\mathrm{Al}-\mathrm{SiC} \\
\mathrm{Al}-\mathrm{SiC}_{\mathrm{p}}\end{array}$ & Stircasting & 11.000 \\
$\begin{array}{l}\text { Composites, UK } \\
\text { Alcan International }\end{array}$ & $\mathrm{Al}-\mathrm{SiC}_{\mathrm{f}}$ & - & 100 \\
$\begin{array}{l}\text { Co-Spray), UK } \\
\text { Pechiney, France }\end{array}$ & $\mathrm{Al}-\mathrm{SiC}$ & Osprey process & 500 \\
COMALCO, Australia & $\mathrm{Al}-\mathrm{Coated}_{\mathrm{p}}$ & Stircasting & - \\
& $\mathrm{Al}, \mathrm{O}_{3}$ & Stircasting & - \\
$\begin{array}{l}\text { Textron Speciality } \\
\text { Materials, USA }\end{array}$ & $\mathrm{Ti}_{-}-\mathrm{SiC}_{\mathrm{f}}$ & & - \\
\hline
\end{tabular}

USA and Japan became active in the area of cast MMCs from mid seventies but the initiative in research was soon wrested by industries from academic institutions leading to, amongst others, the notable Toyota-Dupont collaboration developing cast $\mathrm{Al}-$ $\mathrm{Al}_{2} \mathrm{O}_{3}$ connecting roads and eventually, setting up a plant to produce cast $\mathrm{Al}-\mathrm{SiC}$ ingots. The user industries are buying composite ingots to remelt and cast into components. But, in Japan, the user industry like Toyota motor corporation is vacuum-forming short alumina fibre preforms for infiltration by molten aluminium alloys to cast hub and crankshaft damper pulley reducing their weight by $40 \%$ and $20 \%$ respectively (Fujine et al 1993). Honda is casting an aluminium engine block with integrally cast composite liner containing 12\% alumina and $9 \%$ graphite fibres (Noguchi and Fukizawa 1993). The Japanese strategy, distinctly different from the one followed in USA, is to synthesize the composite within the premises of the user industries. Thus, it is possible to make selective reinforcements in specific locations of a component.

The scenario of MMC summarized above may help the reader to put the development of cast $\mathrm{MMC}$ in the right perspective and realize the importance of challenges posed by different scientific and technological questions related to their synthesis as it will be elaborated in the following sections.

\section{Design of composites}

A composite is a man-made combination of two or more constituents and design of composites for a given application, may address primary issues like selection and distribution of constituent phases, the interfaces and their possible tailoring. In the following subsections, some of the relevant considerations will be highlighted.

\subsection{Selection and distribution of constituent phases}

The traditional composite materials have microstructures containing discrete, dispersed and isolated phase in an otherwise homogeneous matrix-phase. The dispersed phase 
may be continuous along the length as in aligned continuous fibre reinforced composite or discontinuous as in aligned/random short fibre reinforced or particle/whisker reinforced composites. The selection of constituents in a composite depends on the combination of properties required for the targetted application. The level of properties in a proposed composite will depend broadly on distribution and volume fraction of constituent phases. Generally, difference in geometry and distribution of a phase in a matrix, involves considerable cost differential and therefore, both these aspects are apriori decided unless property requirements forbid such a choice. The volume fraction of phase constituents may be determined on the basis of different theoretical models for the necessary properties in the proposed composite of chosen geometry and distribution of phases.

A new class of multiphase composite called interpenetrating phase composite, has emerged and it has a microstructure where each phase is topologically interconnected. Such structures may be described in terms of connectivity and spatial distribution. Nature has engineered many such structures as in bones of mammals and the trunks and limbs of many plants. This kind of composites allows one to combine such properties in different constituent phases requiring continuity, for example, composites where one phase may provide strength and the other may impart conductivity. The principal difficulty lies in assembling such microstructures architecturally on such a fine scale as easily as one does in lay-up procedures. With the development of processing it might be possible to design topological features of such composites on a microscopic scale in order to attain the optimum levels for the combination of properties.

\subsection{Tailoring of interfaces}

In a composite, the constituent phases meet at the interface and often, the nature of interface becomes a factor limiting the contribution of the dispersed phase towards a given property of the composite. A number of routes for processing of composites also demands special attention to the nature of interface. In solidification processing, the dispersoids are stirred/injected into a liquid or semi-solid alloy. The size of the dispersoids are often so small $(\sim 10$ to $50 \mu \mathrm{m})$ that the surface forces are generally dominating over the gravity or buoyancy force. The balance of surface forces at equilibrium may be characterized by the contact angle $\theta$ of Young-Dupre equation as

$$
\operatorname{Cos} \theta=\left(\sigma_{\mathrm{DV}}-\sigma_{\mathrm{DL}}\right) / \sigma_{\mathrm{LV}}
$$

where, $\sigma_{\mathrm{DV}}$ is the surface energy of the dispersoid phase in presence of alloy vapour, $\sigma_{\mathrm{DL}}$ the dispersoid-liquid alloy interface energy and $\sigma_{\mathrm{LV}}$ the surface energy of molten liquid alloy. If the dispersoid phase is wettable by the alloy, i.e. $\theta<90^{\circ}$, it is far easier to transfer dispersoids into the liquid alloy aided by the surface forces. Unfortunately, many of the dispersoids currently of interest in composite research, are not wettable by the chosen alloy matrices as shown in table 2 and therefore, interface tailoring is necessary.

Three approaches have generally been followed to promote wetting of dispersoids by the molten matrix alloy: (i) addition of wetting agent in the alloy, (ii) coating of the dispersoids, and (iii) chemical treatment of the dispersoids. Badia and Rohatgi (1969) used nickel coating on graphite particles in their pioneering efforts to develop 
Table 2. Contact angle and surface properties in selected metal-ceramic systems.

\begin{tabular}{|c|c|c|c|c|c|}
\hline System & $\begin{array}{l}\text { Holding } \\
\text { temp. ( C) }\end{array}$ & $\begin{array}{l}\text { Time } \\
\text { (mins) }\end{array}$ & $\begin{array}{c}\text { Contact angle, } \\
O \text { (degree) }\end{array}$ & $\begin{array}{c}\sigma_{\mathrm{LV}} \\
\left(\mathrm{mJ} / \mathrm{m}^{2}\right)\end{array}$ & $\begin{array}{c}\sigma_{\mathrm{DV}} \\
\left(\mathrm{mJ} / \mathrm{m}^{2}\right)\end{array}$ \\
\hline \multirow[t]{2}{*}{$\mathrm{Al}-\mathrm{SiC}$} & 700 & $\begin{array}{l}10 \\
160\end{array}$ & $\begin{array}{c}125 \pm 10 \\
60 \pm 5\end{array}$ & 860 & 2950 \\
\hline & 800 & $\begin{array}{l}10 \\
160\end{array}$ & $\begin{array}{l}110 \pm 10 \\
55 \pm 5\end{array}$ & 844 & \\
\hline $\mathrm{Al}-\mathrm{Al}_{2} \mathrm{O}_{3}$ & $\begin{array}{l}600 \text { to } \\
1000\end{array}$ & $\begin{array}{l}\text { Steady } \\
\text { state }\end{array}$ & $103-0.05\left(T-T_{\mathrm{m}}\right)^{*}$ & $865-0.05\left(T-T_{m}\right)^{*}$ & 900 \\
\hline Al-oxidized $\mathrm{SiC}$ & 900 & $\begin{array}{l}2 \\
120\end{array}$ & $\begin{array}{r}120 \\
50\end{array}$ & 829 & \\
\hline Al-graphite & 900 & $\begin{array}{l}1 \\
30\end{array}$ & $\begin{array}{l}155 \\
140\end{array}$ & 829 & - \\
\hline $\mathrm{Al}-\mathrm{SiC}$ & 1425 & $\cdots$ & $40 \pm 5$ & 730 & 2910 \\
\hline
\end{tabular}

* $T$, holding temperature; $T_{\mathrm{m}}$, melting point.

Al-graphite cast composite. The present author (Ray 1969) added magnesium to molten aluminium to promote wetting of alumina particles by molten aluminium. Since then, magnesium has been used widely as an addition agent to promote wetting of different ceramic dispersoids like $\mathrm{SiC}$, flyash, mica etc.

Wetting agent when added to the matrix alloy, may work in two ways to reduce wetting angle, $\theta$ - by segregation to the interface and/or by promoting chemical reaction at the interface. Segregation of wetting agent to the interface may change the nature of chemical bond locally at the interface and promote wetting. A chemical reaction at the interface may result in a product covering the entire surface of the dispersoid. The release of energy due to chemical reaction and a change in chemical nature of the surface due to intervening layer of reaction product, may result in wetting.

Chemical reaction is common in metal-oxide composites. Aluminium-alumina composites synthesized by solidification process often reveal a layer of reaction product (as shown in figure 2) which was identified by the author (1969) as magnesium aluminate by X-ray diffraction. Later, it was revealed (Levi et al 1978) that the product could be either $\mathrm{MgO}$ or $\mathrm{MgO} \cdot \mathrm{Al}_{2} \mathrm{O}_{3}$ depending on the level of addition of magnesium.

The oxido-reduction reaction taking place during dispersion of alumina in molten metal $\mathrm{M}$, could be expressed as

$$
3 / 2 \mathrm{M}+1 / 2 \mathrm{Al}_{2} \mathrm{O}_{3} \rightleftarrows 3 / 2 \mathrm{MO}+(\mathrm{Al}) \text {. }
$$

An approximate criterion for reactivity of alumina by $\mathrm{M}$, may be obtained from the equilibrium concentration of $(\mathrm{Al})$ ) in liquid $\mathrm{M}$, released due to chemical reaction (I) and the mole fraction $X_{\mathrm{AL}}$, of aluminium in liquid metal $\mathrm{M}$ is estimated as (Eustathopoulos and Drevet 1993)

$$
X_{\mathrm{AL}}=\exp \left\{-\left(\Delta G_{\mathrm{R}}^{0}+\Delta H_{\mathrm{Al}(\mathrm{M})}\right) / R T\right\}=\exp \left(-\Delta G_{\mathrm{R}}^{*} / R T\right),
$$

where $\Delta H_{\mathrm{Al}(\mathrm{M})}$ is the partial enthalpy of mixing of $\mathrm{Al}$ in $\mathrm{M}$ at infinite dilution and $\Delta G_{\mathrm{R}}^{0}$ 


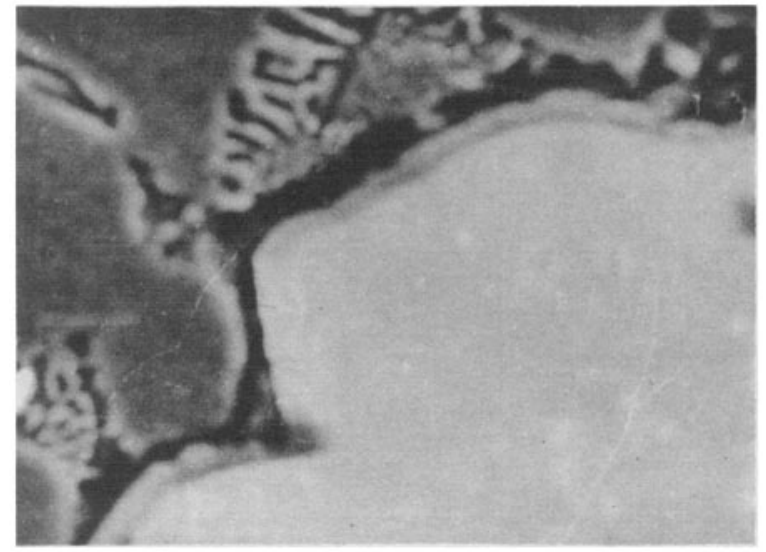

Figure 2. Reaction layer of $\mathrm{MgAl}_{2} \mathrm{O}_{4}$ around an alumina particle dispersed in a matrix of $\mathrm{Al}-\mathrm{Mg}$ alloy.

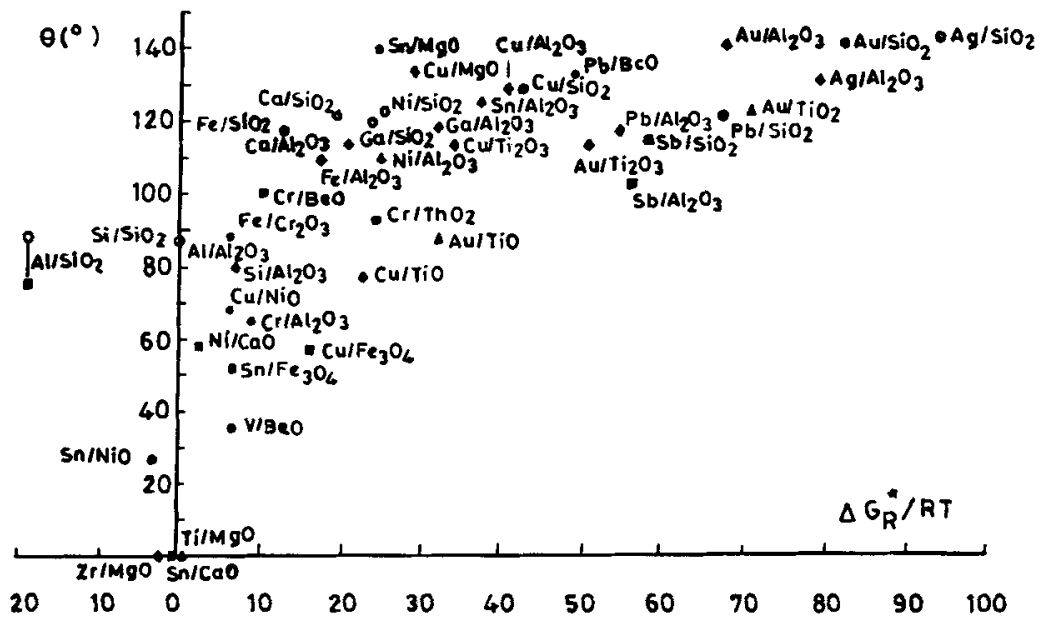

Figure 3. Variation of observed contact angles with $\Delta G_{\mathbf{R}}^{*} / R T$ in different metal-oxide systems.

the free energy change in reaction (I). Figure 3 shows experimental values of contact angle, $\theta$, in various metal-oxide systems as a function of $\Delta G_{\mathrm{R}}^{*} / R T$. It is observed that for high values of $\Delta G^{*} / R T$ corresponding to noble metals on oxides, contact angle, $\theta$, tends towards a limit of $140^{\circ}$ but for lower $\Delta G_{\mathrm{R}}^{*} / R T, \theta$ decreases sharply and a perfect wetting can be achieved in $\mathrm{Tr}$ or $\mathrm{Zr} / \mathrm{MgO}$ systems.

At present, there is no generally acceptable theory to describe the phenomenon of wetting promoted by chemical reaction as outlined above. Laurent et al (1988) proposed that the smallest contact angle, $\theta_{\min }$, observed in a reactive system, may be written as

$$
\operatorname{Cos} \theta_{\min }=\cos \theta_{0}-\left(\sigma_{\mathrm{r}} / \sigma_{\mathrm{LV}}\right)-\left(\Delta G_{\gamma} / \sigma_{\mathrm{LV}}\right),
$$

where, $\theta_{0}$ is the contact angle of liquid $\mathrm{M}$ on a substrate of oxide in absence of chemical reaction, $\sigma_{\mathrm{r}}$ the change in interfacial energies brought about by the reaction product and $\Delta G_{\gamma}$ the change in free energy per unit area, released by the chemical reaction in the immediate vicinity of metal/substrate interface. 
In systems where $\Delta G_{\mathrm{R}}^{*} / R T$ is high and there is no significant chemical reaction, it is possible to alloy such metal with another reactive metal having low values of $\Delta G_{\mathbf{R}}^{*} / R T$ and thereby promote wetting. The reactive metal is generally termed as wetting agent. The chemical reactions are not prevalent in metal oxide systems alone but have been observed also in metal-carbide and metal-carbon systems.

In general, if a dispersoid, $D$, is distributed in a metal matrix $M$ by appropriate technique of synthesis, $M / D$ interface is created. If processing for synthesis requires promotion of wetting by chemical reaction or coating, an intervening layer of coating or reaction product $P$ substitutes $M / D$ interface by $M / P$ and $P / D$ interfaces. Such a situation even when desirable for wetting, may prove harmful from the point of view of properties resulting in the composite. In a discontinuously reinforced structural composite, load is transferred to the dispersoids through matrix. Matching of strain at the interface gives rise to a shear stress and if $M / P$ or $P / D$ interfaces have a lower fracture strength than $M / D$ interface, the load bearing capacity of the composite will be adversely affected. A situation to the contrary may also result if $M / P$ and $P / D$ interfaces have higher fracture strengths than the original $M / D$ interface. Therefore, it is not enough to promote merely wetting as it is also necessary to keep in sight the property of the resulting composite so that it is not adversely affected.

An interface with low fracture energy will fracture at an early stage during loading of a composite containing it. The process of fracture may result in equilibrium surfaces and requires energy $\Gamma_{0}$ to overcome the work of adhesion, $W_{\text {ad }}$, as modified by segregation of elements to the interface.

$$
\Gamma_{0}=W_{\mathrm{ad}}-\Sigma\left(\Delta g_{\mathrm{i}}^{0}-\Delta g_{\mathrm{s}}^{0}\right) C_{\mathrm{i}},
$$

where $C_{\mathrm{i}}$ is the concentration of segregating element i per unit area of interface, $\Delta g^{0}$ the Gibbs free energy change due to segregation to the interface or free surface as denoted by subscripts $i$ and $s$ respectively. The surfaces created by fracture are often not the equilibrium ones and also, their non planar nature results in crack-shielding. Energy dissipation due to plastic deformation also contributes to fracture energy. All these factors enhance the observed fracture energy $\Gamma_{\mathrm{i}}$ related to $\Gamma_{0}$ as

$$
\Gamma_{i}=\$ \Gamma_{0},
$$

where $\$$ is a factor having values lying in the range from 1 to 10 . Evans et al (1990) reviewed interface fracture energy in a number of metal-ceramic bi-material interfaces. In gold-sapphire system $\Gamma_{\mathrm{i}}$ is large $\left(>20 \mathrm{Jm}^{-2}\right)$ compared to the work of adhesion, due to crack blunting caused by slip in gold and bridging of crack surface. However, brittle interface crack extension still occurs. In aluminium-alumina system, fracture never occurs along the interface indicating that $\Gamma_{i}$ exceeds the fracture energy of the constituents. But the interface is often the preferred site for nucleation of voids in the process of ductile fracture of aluminium. In niobium-sapphire system, the basal plane of sapphire is bonded to (110) plane of niobium with $\Gamma_{\mathrm{i}}\left(\sim 70\right.$ to $\left.110 \mathrm{Jm}^{-2}\right)$ larger than either the work of adhesion or the basal plane fracture energy of sapphire.

The design of interfaces in a structural composite should be carried out preferably on the basis of $\Gamma_{\mathrm{i}}$ but the available data base for $\Gamma_{\mathrm{i}}$ is insufficient. The work of adhesion, $W_{\text {ad }}$, although significantly lower than $\Gamma_{\mathrm{i}}$ for metal-ceramic composites, may provide an adequate basis for the design of ceramic-ceramic composites. The database for $W_{\text {ad }}$ for interface between different solids is also very limited. Table 3 shows the work of adhesion observed in a number of metal-ceramic systems following the method 
Table 3. Work of adhesion in selected solid-solid metal-ceramic systems.*

\begin{tabular}{|c|c|c|c|c|c|c|c|c|}
\hline System & $\mathrm{Ni} / \mathrm{ThO}_{2}$ & $\underset{\mathrm{ThO}_{2}}{\mathrm{Ni}_{20} \mathrm{Cr}_{20}}$ & $\begin{array}{l}304 \mathrm{SS} / \\
\mathrm{Al}_{2} \mathrm{O}_{3}\end{array}$ & $\begin{array}{c}\mathrm{Au} / \\
\mathrm{Al}_{2} \mathrm{O}_{3}\end{array}$ & $\begin{array}{c}\mathrm{Ag} / \\
\mathrm{Al}_{2} \mathrm{O}_{3}\end{array}$ & $\begin{array}{c}\mathrm{Cu} / \\
\mathrm{Al}_{2} \mathrm{O}_{3}\end{array}$ & $\begin{array}{c}\mathrm{Ni} / \\
\mathrm{Al}_{2} \mathrm{O}_{3}\end{array}$ & $\begin{array}{r}\mathrm{rFe} / \\
\mathrm{Al}_{2} \mathrm{O}_{3}\end{array}$ \\
\hline Temp. $\left({ }^{\circ} \mathrm{C}\right)$ & 1200 & 1200 & 1200 & 1000 & 700 & 850 & 1000 & 1000 \\
\hline $\begin{array}{l}\text { Work of adh- } \\
\text { esion }\left(\mathrm{mJ} / \mathrm{m}^{2}\right)\end{array}$ & 1100 & 700 & 1440 & 530 & 435 & 475 & 645 & 800 \\
\hline
\end{tabular}

${ }^{*}$ Murr (1975)

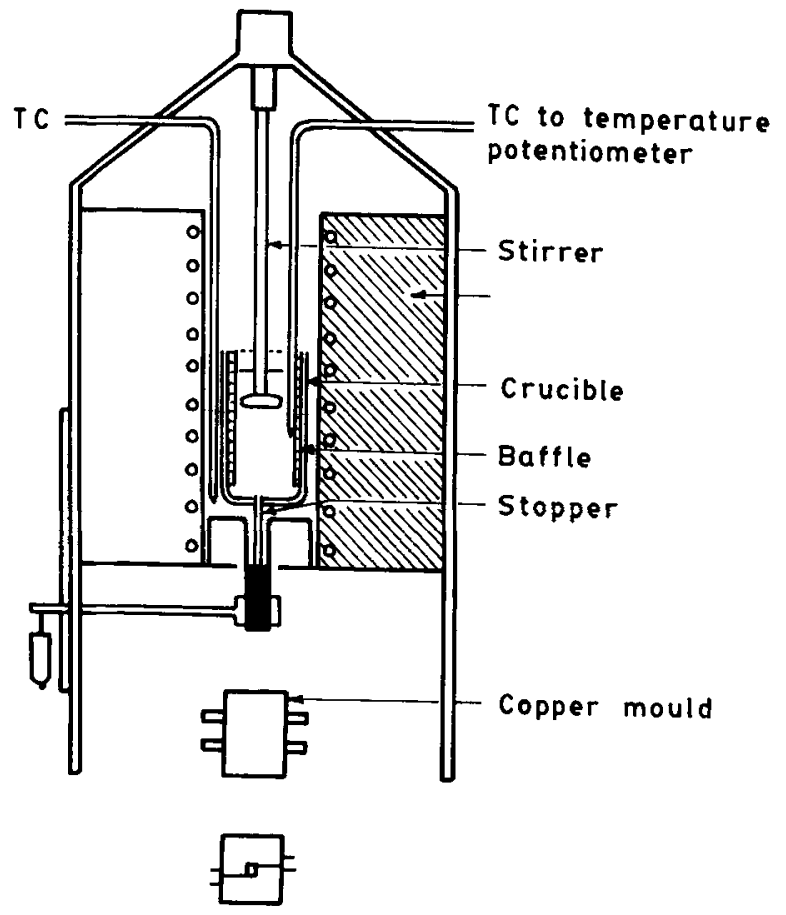

Figure 4. Schematic set-up used for stircasting and compocasting and dimensions of crucible and stirrer.

introduced by Pilliar and Nutting (1967). A tiny drop of liquid metal or alloy is solidified on a substrate and the shape of the drop is equilibrated by holding at the desired elevated temperature. Although the method appears to be reasonable for determination of interface energy or work of adhesion, it has not yet become very popular. There is a need to generate data for different possible interfaces in metal matrix composites of commercial interest. In absence of relevant data, Rohatgi et al (1993) have evaluated the empirical approaches for the determination of interface energies but the results do not appear to be satisfactory. Therefore, apriori assessment of an interface and tailoring the composites so as to contain only desirable interfaces, will have to wait till the relevant knowledge base is generated.

\section{Solidification processing of metal matrix composites}

Synthesis of metal matrix composites requires distribution of dispersoids in the matrix 
alloys. Primarily there are two routes in solidification processing for achieving this goal; (i) by dispersion of dispersoids in liquid metal or alloy through techniques like stirring by an impeller or inert gas bubbling, and (ii) by liquid metal infiltration through a skeletal preform or a bed of dispersoids. The infiltration methods include pressure infiltration, squeeze casting and Lanxide processes. The dispersion methods are stircasting, compocasting and extrusion process like screw extrusion (Ray 1993). The slurry of semisolid or molten alloy containing dispersoids obtained from dispersion method like stircasting, could be spray formed by Osprey process or sprayed into chilled substrate to produce rapidly solidified powders of composite, to be canned for consolidation or extrusion into desired products. Figure 4 shows the schematic diagram of a set-up used by the author for stircasting and compocasting in his laboratory (Ray 1990).

Pressure infiltration technique shown schematically in figure 5, has several advantages. Near-net-shape composite components of complex shape may be fabricated by pressure infiltration and also, the method is amenable to selective reinforcement or various kinds of reinforcement in different locations in a component. But the primary advantage in stircasting or compocasting lies in their ability to use the existing infrastructures of conventional foundries to produce the cheapest composite components. Table 4 shows some practical applications of cast composites for commercial products in Japan (Fukunaga 1993) where squeeze casting is relatively popular.

A number of processes for the synthesis of metal matrix composites have been developed where the dispersoids are not added from outside but are produced by

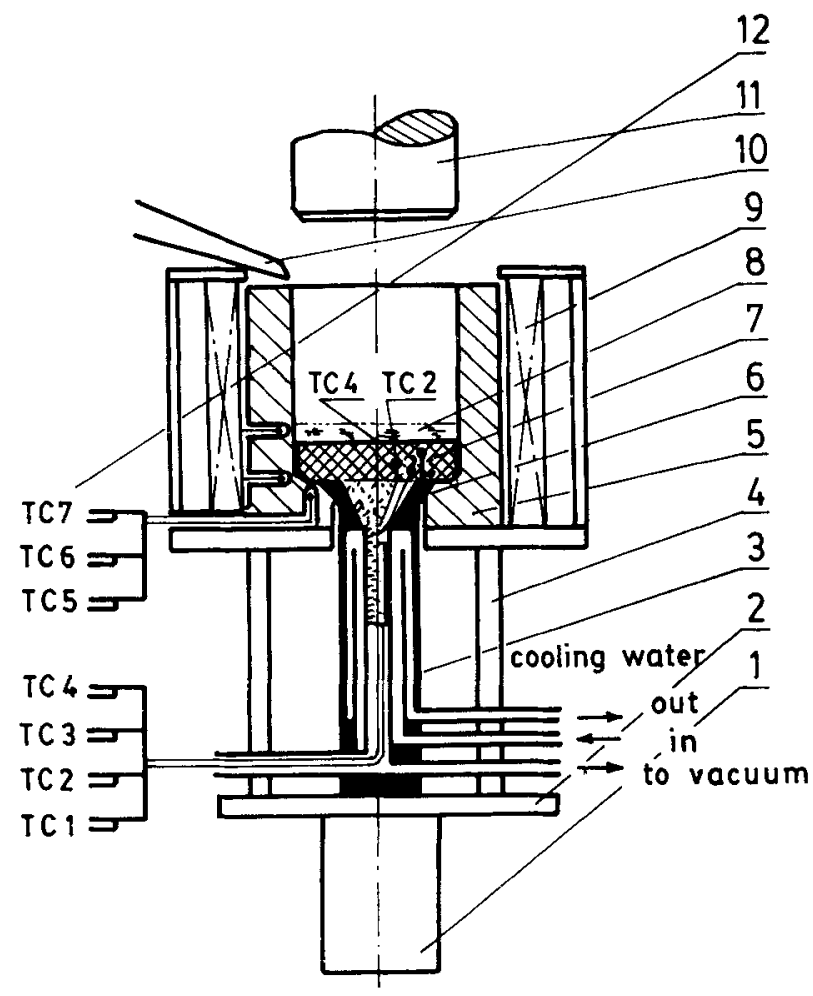

Figure 5. Schematic of squeeze infiltration unit and thermocouple (TC) locations. 
Table 4. Selected application of cast MMCs for commercial products in Japan.

\begin{tabular}{|c|c|c|c|c|}
\hline Product & MMC system & $\begin{array}{l}\text { Method of } \\
\text { manufacture }\end{array}$ & $\begin{array}{l}\text { Characteristics of } \\
\text { applied MMC }\end{array}$ & $\begin{array}{l}\text { Year } \\
\text { (marker) }\end{array}$ \\
\hline $\begin{array}{l}\text { Ring groove } \\
\text { reinforced piston }\end{array}$ & $\mathrm{Al}_{2} \mathrm{O}_{3} / \mathrm{Al}$ alloy & $\begin{array}{l}\text { Squeeze } \\
\text { casting (SC) }\end{array}$ & $\begin{array}{l}\text { Light weight, wear } \\
\text { resistance at high } \\
\text { temperature }\end{array}$ & $\begin{array}{l}1983 \\
\text { (Toyota) }\end{array}$ \\
\hline $\begin{array}{l}\text { Golf goods face } \\
\text { of screwdriver }\end{array}$ & $\mathrm{SiC}_{\mathrm{p}} / \mathrm{Al}$ alloy & $\mathrm{SC}$ & $\begin{array}{l}\text { Light weight, abrasion } \\
\text { resistance }\end{array}$ & $\begin{array}{l}1984 \\
\text { (Nippon } \\
\text { Carbon) }\end{array}$ \\
\hline $\begin{array}{l}\text { Connecting rod of } \\
\text { gasoline engine }\end{array}$ & $\begin{array}{l}\text { SUC fibre/Al } \\
\text { alloy }\end{array}$ & $\mathrm{SC}$ & Specific strength & $\begin{array}{l}1985 \\
\text { (Honda) }\end{array}$ \\
\hline M6-8 bolt & $\mathrm{SiC}_{w} / 6061$ & $\begin{array}{l}\text { SC extrusion } \\
\text { tread rolling }\end{array}$ & $\begin{array}{l}\text { Neutron absorption, } \\
\text { high temperature } \\
\text { strength, little } \\
\text { degassing }\end{array}$ & $\begin{array}{l}1986 \\
\text { (Toshiba) }\end{array}$ \\
\hline $\begin{array}{l}\text { Vane, pressure side } \\
\text { plate of oil pressure } \\
\text { vane pump }\end{array}$ & $\begin{array}{l}\mathrm{Al}_{2} \mathrm{O}_{3} \cdot \mathrm{SiO}_{2}^{\prime} \\
\mathrm{AC} 4 \mathrm{C}\end{array}$ & SC & $\begin{array}{l}\text { Wear resistance, } \\
\text { noise damping }\end{array}$ & $\begin{array}{l}1987 \\
\text { (Hiroshima } \\
\text { Aluminium) }\end{array}$ \\
\hline $\begin{array}{l}\text { Joint of aerospace } \\
\text { structure }\end{array}$ & $\mathrm{SiC}_{w} / 7075$ & $\mathrm{SC}$, rolling & $\begin{array}{l}\text { Specific strength, } \\
\text { low thermal } \\
\text { expansion }\end{array}$ & $\begin{array}{l}1988 \\
\text { (Mitsubishi } \\
\text { Electronics) }\end{array}$ \\
\hline $\begin{array}{l}\text { Rotary compressor } \\
\text { vane }\end{array}$ & $\begin{array}{l}\mathrm{SiC}_{w} / \mathrm{Al}-17 \% \\
\mathrm{Si}-4 \% \mathrm{Cu} \\
\text { alloy }\end{array}$ & $\mathrm{SC}$ & $\begin{array}{l}\text { Specific strength, } \\
\text { wear resistance, low } \\
\text { thermal expansion }\end{array}$ & $\begin{array}{l}1989 \\
\text { (Sanyo) }\end{array}$ \\
\hline $\begin{array}{l}\text { Shock absorber } \\
\text { cylinder }\end{array}$ & $\mathrm{SiC}_{\mathbf{p}} / \mathrm{Al}$ alloy & $\begin{array}{l}\text { Compocasting } \\
\text { SC, extrusion }\end{array}$ & $\begin{array}{l}\text { Light weight, wear } \\
\text { resistance, thermal } \\
\text { diffusion }\end{array}$ & $\begin{array}{l}1989 \\
\text { (Mitsubishi } \\
\text { Aluminium) }\end{array}$ \\
\hline Diesel engine piston & $\mathrm{SiC}_{\mathrm{w}} / \mathrm{Al}$ alloy & SC & $\begin{array}{l}\text { Light weight, wear } \\
\text { resistance }\end{array}$ & $\begin{array}{l}1989 \\
\text { (Niigata) }\end{array}$ \\
\hline Cylinder liner & $\begin{array}{l}\mathrm{Al}_{2} \mathrm{O}_{3}, \mathrm{CF} / \mathrm{Al} \\
\text { alloy }\end{array}$ & $\begin{array}{l}\text { Low } \\
\text { pressure } \\
\text { SC }\end{array}$ & $\begin{array}{l}\text { Light weight, wear } \\
\text { resistance }\end{array}$ & $\begin{array}{l}1991 \\
\text { (Honda) }\end{array}$ \\
\hline Hub of damper & $\begin{array}{l}\mathrm{Al}_{2} \mathrm{O}_{3} \cdot \mathrm{SiO}_{2} / \\
\mathrm{Al}^{\text {alloy }}\end{array}$ & $\mathrm{SC}$ & $\begin{array}{l}\text { Light weight, } \\
\text { reduction of } \\
\text { vibration }\end{array}$ & $\begin{array}{l}1991 \\
\text { (Toyota) }\end{array}$ \\
\hline
\end{tabular}

chemical reaction within the matrix alloy. These composites are often referred to as in situ composites. If one adds graphite powder to molten $\mathrm{Fe}-\mathrm{Ti}$ alloy (Terry and Chinyamakobvu 1991) or titanium powder to molten grey cast iron (Rai et al 1994), one obtains $\mathrm{Fe}$ - TiC composites very similar to commercial "Ferro-TiC" manufactured by powder metallurgy. Similarly, by dispersion of graphite powders in Al-Ti alloy, one may synthesize Al-TiC composites (Koczak and Kumar 1989). The method followed for synthesis is very similar to stircasting or compocasting process in other respects. In another type of process called XD-process, the matrix alloy and the reacting constituents are mixed in the solid state and ignited to generate a self propagating reaction which has to be exothermic and the process results in submicroscopic dispersion of reinforcing particles in a matrix alloy which generally melts because of high heat generated by the reaction (Christodoulu et al 1988). 
Table 5. Ingot manufacturer's recommendations for remelting and casting practice.

\begin{tabular}{|c|c|c|}
\hline \multirow{2}{*}{$\begin{array}{l}\text { Precautions } \\
\text { in respect of }\end{array}$} & \multicolumn{2}{|c|}{ Manufacturer's recommendations } \\
\hline & DURALCAN, USA & COMALCO, Australia \\
\hline A. Premelting & $\begin{array}{l}\text { Ingots: clean, preheated for } \\
\text { drying } \\
\text { Implements: cleaned, coated } \\
\text { and dried }\end{array}$ & $\begin{array}{l}\text { Clean dry tools and } \\
\text { moulds } \\
\text { All steel tools coated } \\
\text { with chromia/alumina/ } \\
\text { zircon/boron nitride }\end{array}$ \\
\hline B. Melting & $\begin{array}{l}\text { Purge furnace with inert gas } \\
\text { (dry argon) } \\
\text { Continue inert gas flow } \\
\text { throughout melting } \\
\text { Do not degas or fiux the melt } \\
\text { Temperature control } \\
\text { mandatory if there is } \\
\text { possibility of chemical } \\
\text { reaction }\end{array}$ & $\begin{array}{l}\text { Inert gas may be used } \\
\text { Skim surface oxides } \\
\text { during air melting } \\
\text { Avoid fluxing or degassing } \\
\text { Temperature control } \\
\text { necessary to avoid } \\
\text { undesirable chemical } \\
\text { reaction }\end{array}$ \\
\hline C. Stirring & $\begin{array}{l}\text { Necessary to counter particle } \\
\text { settling } \\
\text { Avoid turbulence } \\
\text { Manual or automatic }\end{array}$ & $\begin{array}{l}\text { Gentle stirring but } \\
\text { quiet at surface } \\
\text { Induction stirring } \\
\text { not enough } \\
\text { If interrupted, stir } \\
\text { again for ten minutes } \\
\text { at worst case }\end{array}$ \\
\hline D. Pouring & $\begin{array}{l}\text { Avoid turbulence } \\
\text { May use ceramic foam } \\
\text { filters or screens }\end{array}$ & $\begin{array}{l}\text { Prefer bottom pouring } \\
\text { with continued stirring } \\
\text { May use woven fibre } \\
\text { filters or preheated } \\
\text { ceramic foam filters }\end{array}$ \\
\hline $\begin{array}{l}\text { E. Casting } \\
\text { design }\end{array}$ & $\begin{array}{l}\text { Reduce feeding distance by } \\
65 \% \text { of that for base alloy }\end{array}$ & $\begin{array}{l}\text { Enlarge section sizes } \\
\text { of gates and sprues by } \\
25 \% \text { over that for the } \\
\text { base alloy }\end{array}$ \\
\hline
\end{tabular}

In the present article, particular attention is devoted to stircasting process which is now followed for commercial production of composite ingots and the user industries are remelting the ingots and casting composite components in their foundries. This is the cheapest route for the production of composite components.

Processing of stircast composites requires special attention at various stages as summarized by Ray (1994) in table 5 from the recommendations of ingot manufacturers. The considerations for component casting are similar to those which are important during synthesis of cast composite ingots and some of these aspects are covered in the following subsections.

\subsection{Stirring}

During stircasting for synthesis of composites, stirring helps in two ways: (i) to transfer 


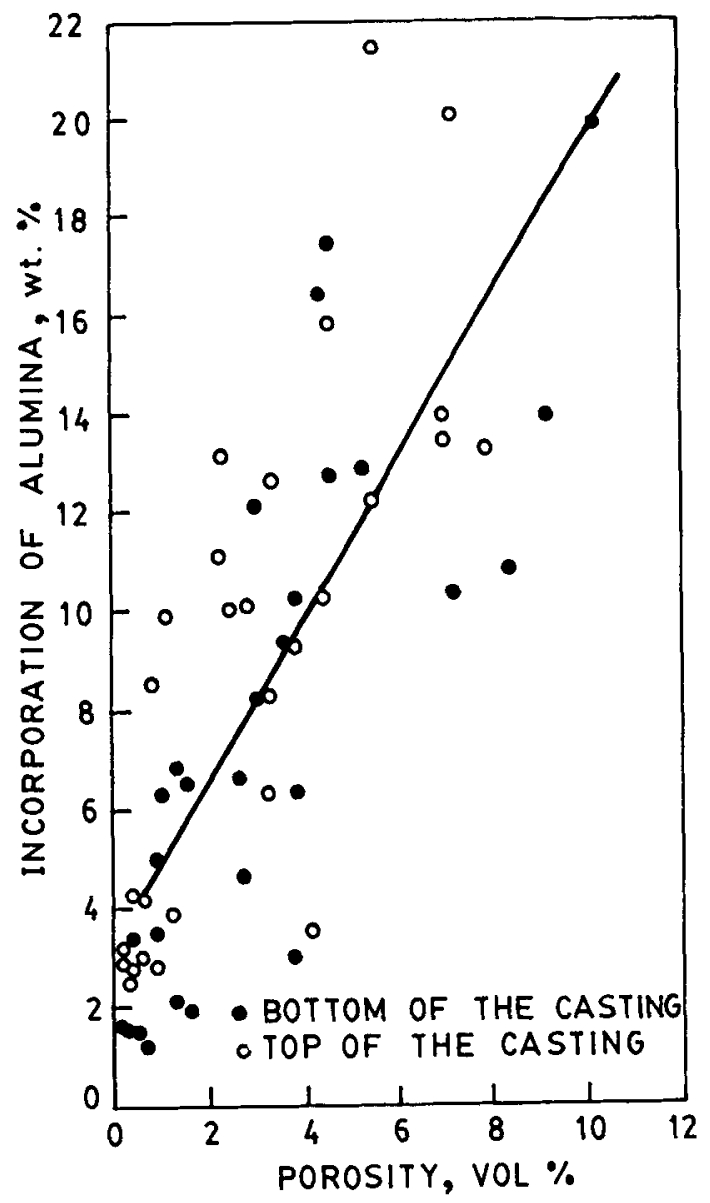

Figure 6. Variation of porosity with alumina content in cast $\mathrm{Al}-\mathrm{Al}_{2} \mathrm{O}_{3}$ composites.

particles into the liquid metal, and (ii) to maintain the particles in the state of suspension. While remelting the ingots, only the latter aspect is relevant. For transferring particles into liquid metals, the development vortex during stirring is observed to be helpful. The dispersoids added to the top of the stirred liquid is drawn towards the centre of the vortex and a larger velocity of rotation at a smaller radial distance from the centre may impart sufficient centrifugal velocity to the dispersoids for their entry into liquid metal. Also, a pressure difference between the inner and outer surfaces of the melt sucks the dispersoids into the liquid (Ghosh and Ray 1988a, b). Unfortunately, air bubbles are also sucked by the same mechanism into liquid metal along with dispersoids resulting in high porosity in cast products. Figure 6 shows the variation of porosity with particle content in cast $\mathrm{Al}-\mathrm{Al}_{2} \mathrm{O}_{3}$ composites synthesized under different conditions of stirring and temperature but with the same design of stirrer. In spite of considerable scatter due to different conditions used, porosity varies almost linearly with particle content in a stircast composite. This observation may either reflect the same mechanism of incorporation of dispersoids and porosity and/or the dispersoids enhancing the stability of bubbles inside the liquid metal. The dispersoids may get attached to bubbles and make their floatation difficult and also the viscosity of the 
liquid is enhanced again reducing the velocity of floatation. Injection of particles with inert gas may also contribute to porosity apart from an increase in cost. It has been possible to reduce the extent of porosity considerably by use of vacuum at the stage of ingot production but use of vacuum during remelting, is strongly discouraged by user industries. Therefore, the ingot manufacturers are recommending for use during remelting some special design of stirrer which maintains a quiet surface at the top. Some research efforts should be directed to devise new methods for incorporation of dispersoids without the associated problem of porosity which compels one to use vacuum during synthesis, adding to the cost of manufacture.

To create homogeneous distribution of dispersoids in molten metal/alloy, stirring the slurry resulting in a high shear rate, gives a fairly uniform distribution in the radial direction and also prevents particle agglomeration (El-Kaddah and Chang 1991). However, distribution in the axial direction will depend on the ability of an impeller to lift dispersoids denser than the molten alloy by the rotating flow created by stirring. Secondary flow in the axial direction results due to transfer of momentum from high to low momentum regions and causes lifting of particles. To correlate particle lifting with flow parameters, one defines a particulate dispersion number (PDN) as the ratio of the axial velocity of secondary flow to the terminal settling velocity. For flow in coaxial rotating cylinder, $\mathrm{PDN}$ is given by

$$
\mathrm{PDN}=\left[H_{0}(\mu \Omega)^{1 / 2}\right] /\left[r_{\mathrm{i}}^{1 / 4} d^{3 / 4} V_{\mathrm{t}}\right],
$$

where, $H_{0}$ is the height of the melt, $\Omega$ the angular velocity of the container, $r_{\mathrm{i}}$ the radius of the inner cylinder, $d$ the gap between the inner and outer cylinders, $V_{t}$ the particle settling velocity and $\mu$ the viscosity of the slurry. If PDN is much greater than one, the settling velocity is smaller than the axial velocity of the secondary flow and the particles will be carried to the top of the melt. On the other hand if PDN is smaller than one, the particles will remain at the bottom. El-Kaddah and Chang (1991) recommended that PDN should be greater than 4 for homogeneous dispersion.

\subsection{Viscosity and casting fluidity of melt dispersoid siurry}

A slurry of molten metal/alloy containing dispersoids has more resistance to flow than the melt alone. Molten metals or alloys generally behave as Newtonian fluid; the shear stress, $\tau$, required to initiate and maintain laminar flow is linearly proportional to the velocity gradient or shear strain rate, $\dot{\gamma}$. The coefficient of viscosity, $\eta$, characterizing the resistance to flow, is constant.

$$
\eta=\tau / \dot{\gamma}=\text { constant }
$$

Melt-dispersoid slurries generally behave differently and the shear stress is not linearly proportional to strain rate. The ratio of shear stress to strain rate is termed apparent viscosity, $\eta_{\mathrm{a}}$,

$$
\eta_{\mathrm{a}}=\tau / \dot{\gamma}=k(\dot{\gamma})^{m}
$$

where, $k$ and $m$ are constants. Horsten et al (1992) determined the apparent viscosity of a slurry of A356 alloy melt containing $18 \mathrm{vol} \%$ silicon carbide particles of average size $13 \mu \mathrm{m}$. At a shear rate of $108 \mathrm{~S}^{-1}$ and below, the slurry has $m=-1 \cdot 3$ indicating a shear 




Figure 7. Variation of apparent viscosity with shear rate in $\mathrm{Al}-7 \mathrm{wt} . \% \mathrm{Si}$ alloy slurry containing 10,15 and $20 \mathrm{vol} . \%$ of $\mathrm{SiC}$ particles.

thinning behaviour, i.e. apparent viscosity reduces as the shear rate caused by stirring increases as shown in figure 7 by Moon et al (1989). At higher shear rates, the cluster of dispersoids are broken reducing the resistance to flow. Also, the apparent viscosity increases with the volume fraction of dispersoids in a slurry.

Higher viscosity helps to enhance the stability of the slurry by reducing the settling velocity. The settling velocity, $V_{\mathrm{s}}$, of a single sphere through an unbounded quiescent Newtonian fluid at zero Reynolds number, has been derived by Stokes as,

$$
V_{\mathrm{s}}(r)=2\left(d_{\mathrm{s}}-d_{1}\right) g r^{2} / 9 \eta
$$

where $r$ is the radius of the sphere and $d_{s}$ its density. $g$ is the acceleration due to gravity, $d_{1}$ the density of the fluid and $\eta$ its viscosity. Since there are many dispersoids settling together in a slurry containing $x$ volume fraction of dispersoids, Richardson and Zaki (1954) proposed an empirical relation to describe settling velocity of a spherical dispersoid of radius $r$ in such a slurry as,

$$
V_{\mathrm{h}}(r, x)=V_{\mathrm{s}}(r)(1-x)^{n},
$$

where $n$ is an exponent and its value depends on the size of dispersoid, size of crucible and particle Reynolds number. It has been observed that higher the volume fraction of dispersoids, the higher will be viscosity as shown in figure 7 . Therefore, the settling velocities $V_{\mathrm{s}}$ and $V_{\mathrm{h}}$ will reduce with increasing volume fraction of dispersoids in a slurry enhancing its stability. But it must also be realized that a high viscosity of slurry will reduce velocity of floatation of bubbles enhancing the possibility of its entrapment inside the slurry.

High viscosity of a slurry will also create resistance to flow in mould channels during casting. Since the problem of flow in the mould is complicated because of accompanying solidification of melt, foundry engineers have devised an experimental parameter called casting fluidity to measure the ability of a melt to flow in a mould before freezing. There are two types of fluidity measurements carried out by pouring the slurry under standard conditions, into a spiral or a strip fluidity mould and the length of cast spiral 


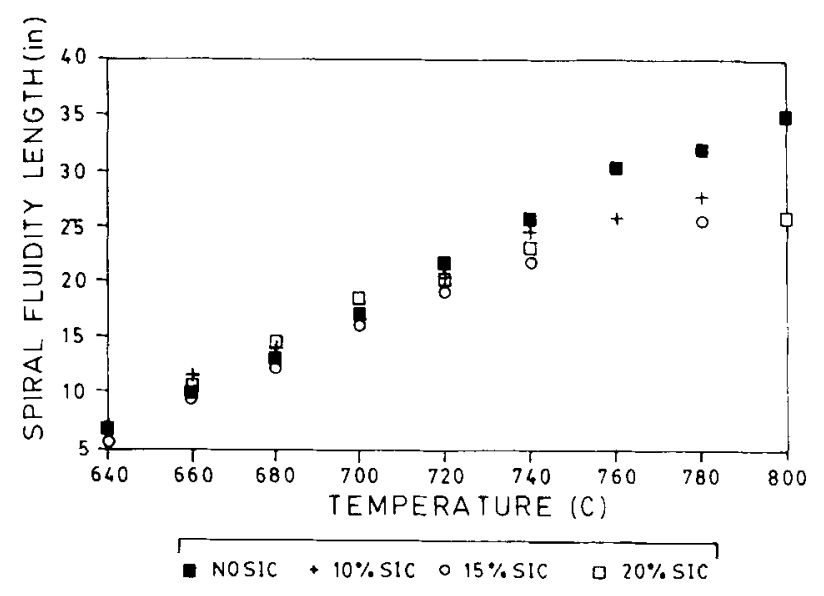

Figure 8. Variation of spiral fluidity length with pouring temperature for A 356 base alloy and slurry containing 10,15 and 20 vol. $\%$ SiC particles.

or strip obtained is a measure of casting fluidity. Flemings (1974) derived an expression for fluidity length, $L_{\mathrm{f}}$, for an alloy as,

$$
L_{\mathrm{f}}=\operatorname{avd}\left(H+C^{*} \Delta T\right) / h_{\mathrm{i}} d_{1}\left(T_{\mathrm{m}}-T_{0}\right)
$$

where $v$ is the velocity of flow of the alloy with melting temperature, $T_{\mathrm{m}}$ having densities $d_{\mathrm{s}}$ and $d_{1}$ in the solid and liquid state respectively, $C$ the specific heat and $H$ the latent heat of melting for the alloy. $\Delta T$ is the extent of superheat in the alloy, $T_{0}$ is the mould temperature and $h_{\mathrm{i}}$ the heat transfer coefficient at mould-metal interface. Figure 8 shows the variation of spiral fluidity length in sand moulds for a slurry of molten A356 alloy containing different volume fractions of silicon carbide particles (Yarandi et al 1993). It is surprising that the fluidity lengths do not decrease significantly in the slurry as compared to that for the A 356 base alloy. One expects a reduction in fluidity length due to a reduction in flow velocity, $v$ for the same metallostatic head but an increase in the density of the slurry may compensate for enhanced viscosity by creating additional pressure. The flow velocity may not therefore change significantly. Further, there is a reduction of latent heat per unit volume which releases lower amount of heat on solidification of a slurry in comparison to that for the alloy alone. Therefore, one expects a relatively faster freezing by conduction of this heat and a reduced fluidity length. But the presence of dispersoids with poor thermal conductivity at mould metal interface contributes to lowering of heat transfer coefficient and so, the fluidity length may not be significantly affected. However, it is also possible that the results for spiral fluidity lengths for the base alloy and the composite slurry are similar in figure 8 , because of settling of particles during flow in the mould channel to result in flow of molten alloy alone even when slurry is being cast.

\subsection{Evolution of solidification microstructure}

During solidification of molten alloy in the slurry there will be evolution of dissolved gases due to difference in solubility of gases in the liquid and solid alloy and presence of dispersoids may help heterogeneous nucleation of gas bubbles on its surface. The 
porosity content of figure 6 includes also the porosity originated during solidification. If the dispersoids are poorly wetting, it will be energetically favourable for the bubbles to nucleate on the dispersoids.

Nucleation of solidifying phases has also been observed in a number of cast composites (Rohatgi et al 1993). These phases often surround the dispersoids completely substituting the dispersoid/primary phase interface by dispersoid/nucleating phase and nucleating phase/primary phase interfaces. If such a substitution is favourable from the point of view of properties, one may try to tailor heterogeneous nucleation of solidifying phases accordingly.

During solidification of slurry, the temperature reduces below the liquidus temperature to make the molten alloy unstable with respect to formation of primary phase. Classical nucleation theory considers the total free energy change for the solidification of a crystal of $n$ atoms as,

$$
\Delta G=-n V_{\mathrm{a}} \Delta G_{\mathrm{v}}+M n^{2 / 3} \Delta \sigma
$$

where $\Delta \sigma=\sigma_{\mathrm{SL}}+\sigma_{\mathrm{SD}}-\sigma_{\mathrm{DL}} \cdot V_{\mathrm{a}}$ is the atomic volume of solidifying interface, $\Delta G_{\mathrm{v}}$ the change in chemical free energy per unit volume due to solidification, $M$ is a geometrical factor and $\sigma$ the interfacial energy between phases indicated by subscripts S, D and L to denote the solidifying phase, the dispersoid and the liquid alloy respectively. Heterogeneous nucleation behaviour may be manipulated by controlling $\Delta G$ which in turn requires knowledge of interface energies. A lack of data base for interface energies has already been commented upon earlier and it is an obstacle for manipulation to the advantage of the properties in the present context also.

The ceramic dispersoids which generally have lower thermal conductivity than that of the melt, are often surrounded by the last freezing fraction of the molten alloy during solidification of slurry. This phenomenon has been interpreted so far, in terms of particle pushing by solidification front taking cue from the famous study of Uhlmann et al (1964) on interaction of particles with planar solidification front. They observed that for every size of particle, there is a critical velocity of solidification front below which the particle is pushed by the front and above this critical velocity the particle is likely to be engulfed by the solidifying phase. There are diverse approaches of various authors (Chernov and Melnikova 1965: Cisse and Bolling 1971; Sasikumar et al 1989) to understand this phenomenon but an absence of size specificity in the context of cast composite is quite striking. Kang et al (1994) investigated one dimensional heat transfer during solidification of $\mathrm{Al}-\mathrm{Al}_{2} \mathrm{O}_{3}$ slurry and concluded that the dispersoids act as barrier to heat and mass transfer and therefore, the dispersoids are surrounded by solute rich liquid cooling at a relatively slower rate. In spite of limited nature of one dimensional model, the author believes that further investigations along these lines should be undertaken for a complete understanding of heat and mass transfer taking place during solidification of composites and their consequence on microstructure.

\section{Conclusions}

The history of metal matrix composite is only two and a half decades old compared to thousands of years of our experience with monolithic metals and alloys. 1t is obvious that there is a long way to go before we are able to explore full potential of these novel materials where human ingenuity can display itself to a very large extent. 
So far, the main focus of research has been on developing different routes of synthesis of metal matrix composites and we have to-day a number of choices. The scientific issues involved in synthesis have been outlined in the context of various routes of synthesis and many of the challenging problems outlined in the present article are for the scientist to take up and evolve appropriate methods to tackle them. The technologists should now shift their attention to other areas like forming of net-shape or near net-shape components of composites. A beginning has already been made by Dowty Rotol Ltd., UK, assessing forging properties of particle reinforced composites supplied by companies in UK and USA. Pera International in collaboration with NPL, UK, is engaged in evaluating machining techniques. TWI, Abingdon, UK, is involved in assessing joining techniques for application in metal matrix composites. Our laboratory at University of Roorkee has shifted attention to TIG welding of MMCs and the problem of two-phase flow in mould channels during casting. It is expected that the research initiatives in these areas will intensify in future.

\section{References}

Badia F A and Rohatgi P K 1969 Trans. AFS 79346

Charles D 1990 Metall. Mater. 678

Chernov A A and Melnikova A M 1965 Kristallografiya 10672

Christodoulu L, Parrish P A and Crowe C R 1988 MRS Symp. Proc. 12029

Cisse $\mathbf{J}$ and Bolling G F $1971 \mathrm{~J}$. Cryst. Growth 1125

El-Kaddah N E and Chang K E 1991 Mater. Sit. Eny. A144 221

Eustathopoulos N and Drevet B 1993 MRS Simp. Proc, 31415

Evans A G, Ruhle M, Dalgleish B J and Charalambides P G 1990 Metall. Trans. A21 2419

Flemings M C 1974 Solidification processing (New York: McGraw Hill) p. 219

Fujine M, Kaneko T and Okijama J 1993 Adr. Mater. Proc. 6120

Fukunaga H 1993 Proc. 9 th int. conf. on composite materials, Madrid. Spain p. 1335

Ghosh P K and Ray S 1988a Trans. JIM 29502

Ghosh P K and Ray S 1988 b Trans. AFS 88775

Hartmann W and Kellerer H 1985 Adnanced materials research and development for transport composites (Paris: Ed. de Phisique) p. 3

Horsten M G, Quaak G J and Kool W H 1992 Proc. conf. on processing of semi-solid alloys and composites (USA: MIT) p. 359

Kang C G, Ray S and Rohatgi P K 1994 Mater. Sci. Eng. A188 193

Koczak M J and Kumar K S 1989 US Patent No. 4. 806, 372

Laurent V. Chatain D and Eustathopoulos N 1991 Mater. Sci. Eng. A135 89

Levi C G, Abbaschian G J and Mehrabian R 1978 Metall. Trams. A9 697

Moon H K, Ito Y, Cornie J and Flemings M C 1993 Key Engy. Mater. 79-80 15

Murr L E 1975 Interfacial phenomena in metals and alloys (USA: Addison-Wesley) p. 286

Noguchi $M$ and Fukizawa K 1993 Adt. Mater. Proc. 620

Pilliar R M and Nutting J 1967 Philos. Mag. 16181

Rai V, Nath S K and Ray S 1994 Proc. symp. of 9th ISME cony.. Roorkee p. 407

Ray S 1969 M. Tech. Dissertation. Indian Institute of Technology, Kharagpur

Ray S 1990 Indian J. Technol. 28368

Ray S 1993 J. Mater. Sci. 285397

Ray $S 1994$ Indian Foundry $J, 37$

Richardson J K and Zaki W N 1954 Trans. IChE 323

Rohatgi P K. Ray S, Asthana R and Narendranath C S 1993 Mater. Sci. Eng. A162 163

Sasikumar R, Rammohan T R and Pai B C 1989 Acra Metall. 372085

Terry B S and Chinyamakobvu 1991 J. Mater. Sci. 10628

Uhlmann D R, Chalmers B and Jackson K A 1964 J. Appl. Phys. 352986

Yarandi F M, Rohatgi P K and Ray S 1993 Key Enyg. Mater. 79-80 91 